\title{
DEZENFEKSİYONUN MAKSİLLOFASİYAL SİLİKON ELASTOMERİN FİZİKSEL ÖZELLİKLERİ ÜZERİNE ETKİLERİ ${ }^{*}$
}

\author{
EFFECTS OF DISINFECTION ON THE PHYSICAL PROPERTIES OF A \\ MAXILLOFACIAL SILICONE ELASTOMER ${ }^{*}$
}

\author{
Arş. Gör. Dr. Meral KURT* \\ Doç. Dr. Merve BANKOĞLU GÜNGÖR*
}

Dt. Necla KILIÇKAYA*

Prof. Dr. Seçil KARAKOCA NEMLí

\author{
Makale Kodu/Article code: 3861 \\ Makale Gönderilme tarihi: 24.10 .2018 \\ Kabul Tarihi; 14.02.2019 \\ DOI : $10.17567 /$ ataunidfd.527021
}

\author{
Meral Kurt: ORCID ID: 0000-0002-3225-4983 \\ Necla Kılıçkaya: ORCID ID: 0000-0003-2539-2621 \\ Merve Bankoğlu Güngör: ORCID ID: 0000-0002-4002-6390 \\ Seçil Karakoca Nemli: ORCID ID: 0000-0001-8836-0673
}

\section{Öz}

Amaç: Bu çalışmanın amacı farklı dezenfeksiyon işlemlerinin maksillofasiyal silikon elastomerin yüzey pürüzlülüğü ve renk stabilitesi üzerine etkisinin değerlendirilmesidir.

Gereç ve Yöntem: Maksillofasiyal silikon (M511; Technovent) materyalinden 60 adet disk şeklinde (15 mm çapında $3 \mathrm{~mm}$ kalınlığında) örnek hazırlandı. Örnekler dezenfeksiyon işlemlerine göre; 1) kontrol (distile su), 2) efervesan tablet (Corega), 3) nötral sabun (Sebamed), 4) dermal dezenfektan (Biorad Derm), 5) klorheksidin glukonat (Andorex) ve 6) otoklav olmak üzere altı gruba ayrıldı $(n=10)$. Dezenfeksiyon işlemi otoklav grubu hariç günde iki defa 15 gün boyunca uygulandı. otoklav grubunda ise dezenfeksiyon toplamda 3 defa yapıldı. Renk ölçümleri, dezenfeksiyon işlemi öncesi ve sonrasında spektrofotometre ile gerçekleştirildi. Renk parametreleri kaydedilerek $\Delta \mathrm{E} 00$ değerleri hesaplandı. Yüzey pürüzlülüğü (Ra) ölçümleri ise dezenfeksiyon işlemi öncesi ve sonrasında profilometre cihazı ile gerçekleştirildi. Elde edilen veriler; tek yönlü ANOVA ve tekrarlayan ölçümler için ANOVA testleri kullanılarak istatistik olarak analiz edildi $(a=0,05)$.

Bulgular: Otoklav grubunda $\triangle \mathrm{E} 00$ değerleri $(3,79)$; diğer gruplardan anlamlı derecede daha yüksek bulunurken diğer gruplar arasında istatistik olarak anlamlı fark yoktur $(0,92-1,37)(P>0,05)$. Dezenfeksiyon işlemi öncesi ve sonrasında yüzey pürüzlülüğü değerlendirildiğinde dezenfeksiyon sonrası kontrol, efervesan tablet, nötral sabun, ve dermal dezenfektan gruplarında yüzey pürüzlülüğü değerleri anlamlı derecede daha yüksek bulundu $(P<0,05)$. Nötral sabun grubunun dezenfeksiyon sonrası yüzey pürüzlülüğü değeri klorheksidin glukonat ve otoklav gruplarından anlamlı derecede daha yüksek bulundu $(P<0,05)$.

Sonuç: Otoklavda yapılan dezenfeksiyon işleminin maksillofasiyal silikon elastomerin renk değişimi üzerinde önemli etkisi bulunmaktadır. Dezenfeksiyon işlemleri genellikle maksillofasiyal silikon elastomerin yüzey pürüzlülüğünü arttırmaktadır.

Anahtar kelimeler: dezenfeksiyon; maksillofasiyal protez; renk; silikon elastomerler

\section{ABSTRACT}

Aim: The purpose of this study was to evaluate the effects of different disinfection procedures on the surface roughness and color stability of the maxillofacial silicone.

Material and Methods: Sixty disc-shaped specimens (15 $\mathrm{mm}$ in diameter and $3 \mathrm{~mm}$ in thickness) were fabricated from a maxillofacial silicone rubber (M511; Technovent). The specimens were divided into six groups according to the disinfection procedures: 1) control (distilled water), 2) effervescent tablets (Corega), 3) neutral soap (Sebamed), 4) dermal disinfectant (Biorad Derm), 5) chlorhexidine gluconate (Andorex), and 6) autoclave $(n=10)$. Disinfection was performed two times a day for 15 days except group autoclave. In the group autoclave disinfection was applied for three times in total. Color measurements were performed by using a spectrophotometer before and after disinfection process. Color parameters were recorded and $\Delta \mathrm{E} 00$ values were calculated. Surface roughness $(\mathrm{Ra})$ were measured before and after disinfection process, using a contact stylus profilometer. Data were statistically analyzed using one-way and repeated measures of ANOVA tests $(a=0.05)$.

Results: Group autoclave showed the significantly higher $\Delta \mathrm{E} 00$ values (3.79) among the groups, while the $\Delta \mathrm{E} 00$ values of the other groups $(0.92-1.37)$ were not statistically significant $(p>0.05)$. When surface roughness were evaluated, the Ra values were significantly higher in control, effervescent tablets, neutral soap, and dermal disinfectant groups after the disinfection methods $(p<0.05)$. The Ra values of group neutral soap after the disinfection were found significantly higher than chlorhexidine and autoclave groups $(\mathrm{p}<0.05)$.

Conclusion: Autoclave disinfection had a significant impact on the color change of maxillofacial silicone. Disinfection procedures generally increased surface roughness.

Key Words: color; disinfection; maxillofacial prosthesis; silicone elastomers

* Gazi Üniversitesi Diș Hekimliği Fakültesi, Protetik Diș Tedavisi Anabilim Dalı, Ankara

$\neq$ 1. Uluslararası Dental ve Oral Enfeksiyonlar Kongresi (1. International Congress of Dental and Oral Infections) konqresinde özet bildiri halinde sözlü olarak sunulmustur. (07-09 EVlül 2018 Sakarva - TÜRKİYE)

Kaynakça Bilgisi: Kurt M, Kılıçkaya N, Bankoğlu Güngör M, Karakoca Nemli S. Dezenfeksiyonun Maksillofasiyal Silikon Elastomerin Fiziksel Özellikleri Üzerine Etkileri. Atatürk Üniv Diş Hek Fak Derg 2020; 30: 274-281.

Citation Information: Kurt M, Kilickaya N, Bankoglu Gungor M, Karakoca Nemli S. Effects of Disinfection on the Physical Properties of a Maxillofacial Silicone Elastomer. J Dent Fac Atatürk Uni 2020; 30: 274-281. 


\section{GİRİŞ}

Çene yüz defektleri; kanser, travma ve doğumsal deformiteler sebebiyle ortaya çıkmaktadır. ${ }^{1,2}$ Yüz protezleri, çene yüz defektini estetik açıdan restore edebilmeli ve hastanın yaşam kalitesini arttırılabilmelidir. ${ }^{3,4}$ Silikon materyali; kimyasal stabilitesi, yüzey yapısı, dayanıklıı̆̆ı ve manipülasyon kolaylığı nedeniyle çene yüz protezlerinin üretiminde 50 yılı aşkın süredir kullanılmaktadır. ${ }^{5-8}$ Ancak bu materyalin renk özelliklerinde zamanla değişiklikler ve bozulmalar gerçekleşmektedir. $^{9-11}$ Yüz protezlerinin yenilenme gerekliliğindeki temel sebep yüzey yapısı ve renginde gerçekleşen bu bozulmalardır. ${ }^{12,13}$ Yapılan anketlerde hastaların protezleriyle ilgili memnuniyetsizlik sebeplerinin en başında protezin renginde meydana gelen soluklaşmaların geldiği bildirilmiştir. ${ }^{10}$ Çene yüz protezlerindeki bu bozulmalar ultraviyole (UV) ışınları, hava kirliliği, ISInem değişimleri, kullanım hataları veya temizleyici ajanlar sebebiyle gerçekleşmektedir. ${ }^{4,9,14-17}$

Diğer yandan yüz protezlerinin hijyen yetersizlikleri cerrahi operasyon geçirmiş defekt bölgesinin sağlığını olumsuz yönde etkilemekte enfeksiyon riskini arttırmaktadır. ${ }^{13,17} \mathrm{Bu}$ nedenle çevre dokuların sağlığının korunabilmesi için yüz protezlerinin uygun şekilde dezenfeksiyonu şarttır. Yapılan bazı çalışmalarda oldukça hassas yapılsa bile protezlerin temizliği sırasında parmakla ovmanın protezin renk uyumunu sağlayan yüzey boyalarının ve yapısındaki çeşitli materyallerin uzaklaşmasına neden olduğu belirtilmiştir. ${ }^{4,12,18,19}$

Silikon yüz protezlerinin temizliğinde kullanılan diğer bir seçenek ise çeşitli kimyasal solüsyonlarda bekletmektir. ${ }^{12}$ Ancak bu solüsyonlar (nötral sabun, sodyum hipoklorit \%1, temizleyici tabletler, piyasada mevcut antimikrobiyal solüsyonlar ve klorheksidin), konsantrasyonları ve uygulama yöntemi için birçok farklı seçenek bulunmaktadır ve bu seçeneklerin hepsi silikon materyalin özelliklerinde değişikliklere sebep olmaktadır. ${ }^{10,12,19,20}$ Son zamanlarda yapılan çalışmalar incelendiğinde silikon yüz protezlerinin dezenfeksiyonu için ideal solüsyon konusunda halen net bir sonuca varılmamıştır. ${ }^{4,19,20}$ İnsan vücudunda dokularla temasta olan protetik materyallerin dezenfeksiyonunda kimyasal solüsyonlar birçok bakteri üzerinde etkin olmasına rağmen sporlar üzerindeki etkisiz kalabilmektedirler. $\mathrm{Bu}$ nedenle otoklavla sterilizasyon önerilmektedir. Otoklav, sterilizasyon yöntemleri arasında en etkin olanıdır. ${ }^{21}$ Otoklav yöntemi, çeşitli dental alet ve dental materyallerin dezenfeksiyonunda yıllardır kullanılmakta olmasına rağmen bu yöntemin yüz protezlerinde kullanılan silikon materyaline etkisi üzerine çalışmaya rastlanılmamıştır.
Biyolojik ortamlarda kullanılan yapay materyallerin yüzey pürüzlülüğü çok önemli bir fiziksel özelliktir. Yüzey pürüzlülüğü, mikroorganizmaların materyal yüzeyine tutulumunu etkileyen en önemli etken olarak bilinmektedir. ${ }^{22-24} \mathrm{Bu}$ sebeple yüz protezlerinin yapımı esnasında protezlerin doku ile temasta olan yüzeylerinin pürüzlülüğünün azaltılması hedeflenmektedir. $^{8}$ Yüzey pürüzlülüğü ayrıca materyalin mekanik özelliklerinin de önemli bir göstergesidir. Çünkü materyalde gerçekleşen bozulmalarla birlikte yüzeyde çukurcuklar ve düzensizlikler meydana gelerek yüzey pürüzlülüğü artmaktadır. Yüzeyde oluşan bu çukurcuklara ve düzensizliklere çeşitli kalıntıların birikmesiyle hem enfeksiyon riski artmakta hem de protezin görünümü değişmektedir. ${ }^{25,26}$ Protetik materyallerin üretim sonrası düzgün bir yüzey topografisi göstermeleri yanında kullanım esnasında da bulundukları biyolojik ortamda ve diğer çevresel koşullar altında bu düzgün yüzey yapısını korumaları gerekmektedir.

Bu çalışmada çeşitli kimyasal dezenfektanlar ve otoklav ile yapılan dezenfeksiyonun maksillofasiyal silikon elastomerin yüzey pürüzlülüğü ve renk stabilitesi üzerine etkisinin değerlendirilmesi amaçlanmıştır. Bu çalışmanın sıfır hipotezi, kullanılan dezenfeksiyon yöntemlerinin maksillofasiyal silikonların yüzey pürüzlülüğü ve renginde değişime neden olmayacağıdır.

\section{MATERYAL VE METOD}

Bu çalışmada kullanılan materyaller Tablo 1'de gösterilmektedir. Silikon örneklerin polimerize edileceği alçı kalıpların hazırlanması amacıyla $15 \mathrm{~mm}$ çapında 3 mm kalınlığında disk şeklinde 60 adet mum örnek hazırlandı. Mum örnekler beyaz sert alçı ile muflaya alındılar ve alçı serleştikten sonra muflalar ısıtılıp açılarak mum uzaklaştırıldı. Sıcak su ile temizlenen alçı yüzeyleri lak (Akrolak; Koca Kimya ve Dental Ltd., Ankara, Türkiye) ile izole edildi. Silikon elastomer örneklerin hazırlanması için yüksek ısıda ilave tip reaksiyon ile polimerize olan silikon elastomer (M511; Technovent Ltd., Newport, UK) kullanıldı. Örnekler hazırlanırken iki parça halinde bulunan silikon setinin baz ve katalizör kısımları üretici firma önerileri doğrultusunda 10:1 oranında (20 gr part A, 2 gr part B) hassas terazi ile tartılarak karıştırıldı karışıma $4 \mathrm{gr}$ pigment (pink, QuickWeigh LSR; Spectromatch Ltd, Bath, UK) ilave edildi. Silikon karışımı kalıba yerleştirilip kalıp kapatıldıktan sonra $100^{\circ} \mathrm{C}$ sıcaklıktaki fırında 1 saat polimerize edildi. Oda sıcaklığında soğumaya bırakılan kalıplar açılarak örnekler çıkarıldı, kenarlarındaki fazlalıklar kesildi. Yüzeydeki alçı ve alçı ayırıcı 
kalıntılarından arındırmak için önce akan su altında yıkandı daha sonra ultrasonik temizleyicide oda sıcakIığındaki distile su içinde $5 \mathrm{dk}$ temizlendikten sonra örnekler kurutularak ışık görmeyen ortamda 24 saat bekletildi.

Tablo 1. Çalışmada kullanılan materyaller

\begin{tabular}{|l|l|l|}
\hline Materyal & Marka & Üretici firma \\
\hline $\begin{array}{l}\text { Silikon } \\
\text { elastomer }\end{array}$ & M511 & $\begin{array}{l}\text { Technovent Ltd., } \\
\text { Newport,UK }\end{array}$ \\
\hline Renk pigmenti & QuickWeigh LSR & Spectromatch Ltd., Bath, UK \\
\hline $\begin{array}{l}\text { Efervesan } \\
\text { tablet }\end{array}$ & Corega & $\begin{array}{l}\text { Stafford Miller Ltd., } \\
\text { Dungarvan, İlanda }\end{array}$ \\
\hline Nötral sabun & $\begin{array}{l}\text { Sebamed ph5,5 } \\
\text { Likit Yüz ve Vücut }\end{array}$ & $\begin{array}{l}\text { Sebapharma GmbH., } \\
\text { Boppard, Almanya }\end{array}$ \\
\hline $\begin{array}{l}\text { Dermal } \\
\text { dezenfektan }\end{array}$ & Biorad Derm & $\begin{array}{l}\text { Necm Kimya, İstanbul, } \\
\text { Türkiye }\end{array}$ \\
\hline $\begin{array}{l}\text { Klorheksidin } \\
\text { glukonat }\end{array}$ & Andorex & $\begin{array}{l}\text { Pharmactive İlaç Sanayi ve } \\
\text { Tic AŞ. İstanbul, Türkiye }\end{array}$ \\
\hline
\end{tabular}

Örneklerin, dezenfeksiyon işlemi öncesi renk ölçümleri spektrofotometre (CM-2300d, Konika Minolta Inc., Osaka, Japonya) ile (illuminant D65, aydınlatma geometrisi d/8 derece, standard gözlemci $10^{\circ}, \mathrm{MAV}$ : $8 \mathrm{~mm}, \mathrm{SCI}$ mod) beyaz zemin üzerinde gerçekleştirildi. Her bir örnekten 3 ölçüm yapılarak ortalama renk parametreleri kaydedildi. Tüm örneklerin yüzey pürüzlülükleri (Ra) profilometre (MarSurf M 300C, Mahr, Göttingen, Almanya) (Lt =5,6 mm, stylus PHT 6-350/2 $\mu \mathrm{m})$ ile ölçüldü. Profilometre cihazı her grubun ölçümü öncesinde kalibre edildi.

Örnekler dezenfeksiyon işlemlerine göre 6 alt gruba ayrıldı $(n=10)$.

1) Kontrol (distile su): Örnekler distile suyun içinde $10 \mathrm{dk}$ bekletilip kuruland.

2) Efervesan tablet: Temizleyici tablet (Corega; Stafford Miller Ltd., Dungarvan, İrlanda) Ilık suya atıldı. Örnekler üretici firmanın uygulama talimatları doğrultusunda tabletin köpürüp çözündüğü suda $5 \mathrm{dk}$ bekletilip duruland.

3) Nötral sabun: Bu gruptaki her bir örnek deterjan içermeyen temizleyiciyle (Sebamed ph5,5 Likit Yüz ve Vücut; Sebapharma GmbH., Boppard, Almanya) 30 sn parmakla ovularak köpürtüldü ve akan suyun altında durulandı.

4) Dermal dezenfektan: Alkol bazlı el cilt dezenfektanı (Biorad Derm; Necm Kimya, İstanbul, Türkiye) her bir örneğin yüzeyine sıkılarak uygulandı, 30 sn bekletildikten sonra akan suyun altında durulandı.

5) Klorheksidin glukonat: Örnekler klorhexidin içeren solüsyonun (Andorex; Pharmactive İlaç Sanayi ve Tic AŞ. İstanbul, Türkiye) içinde $10 \mathrm{dk}$ bekletilip durulandı.

6) Otoklav: Örnekler otoklavda $134{ }^{\circ} \mathrm{C}$ de 2 bar basınç altında $10 \mathrm{dk}$ boyunca tutuldu.

Dezenfeksiyon işlemi otoklav grubu hariç günde iki defa 15 gün boyunca uygulandı. Otoklav grubunda ise dezenfeksiyon işlemi toplamda 3 defa yapıldı. Renk ve yüzey pürüzlülüğü ölçümleri dezenfeksiyon işlemleri sonrasında tekrarlandı.

Başlangıç ve dezenfeksiyon işlemleri sonrasında elde edilen ortalama renk parametreleri arasında CIEDE2000 renk farkı sistemine göre renk değişimi $\left(\Delta E^{\prime}\right)$ hesaplandı. Hesaplamalar için aşağıdaki formül kullanıldı ${ }^{27,28}$;

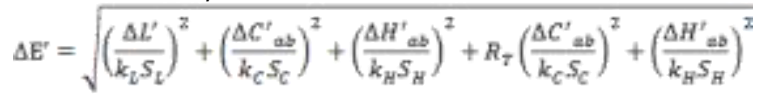

$\Delta \mathrm{L}^{\prime}, \Delta \mathrm{C}^{\prime}$ ve $\Delta \mathrm{H}^{\prime}$, sırasıyla örneklerin işlem öncesi ve sonrası parlaklık (lightness), renk yoğunluğu (chroma) ve renk tonu (hue) ölçümleri arasındaki farklarıdır. $S_{L}, S_{C}$ ve $S_{H}, C I E L A B$ sisteminde gözlenen düzensizlikleri gidermek amacıyla formüle eklenen ağırlık fonksiyonlarıdır (weighting functions). $k_{L}$, $k_{C}$ ve $k_{H}$ parametrik faktörleri, deneysel koşullara bağlı hatalar için düzeltme terimleridir. $\mathrm{R}_{\mathrm{T}}$ (rotasyon fonksiyonu) ise mavi alandaki renk yoğunluğu ve renk tonu farkıııkları arasındaki etkileşim miktarını gösteren fonksiyondur. ${ }^{27,28}$

\section{Istatistiksel Analiz}

Elde edilen tüm verilerin analizi (IBM SPSS Statistics for Windows, Version 20.0; IBM Corp, Armonk, NY, USA) paket programında yapıldı. Verilerin normal dağılım gösterip göstermediği Shapiro-Wilk testi ile değerlendirildi. Gruplara ait E00 verileri, tek yönlü ANOVA ile test edildi. İkili karşılaştırmalar için TUKEY HSD testi kullanılarak istatistik olarak analiz edildi. Gruplara ait yüzey pürüzlülüğü verileri, tekrarlayan ölçümler için ANOVA ile test edildi. Sferisite varsayımının sağlanmadığı durumlarda Greenhouse-Geisser düzeltmesi kullanıldı. Tüm sonuçlar $\mathrm{a}=0,05$ için anlamlı kabul edildi.

\section{BULGULAR}

Deney gruplarına ait ortalama $\Delta \mathrm{E} 00$ değerleri ve standart sapmaları Tablo 2'de ve Şekil 1'de gösterildi. Dezenfeksiyon yöntemlerine ait $\Delta \mathrm{E} 00$ değerleri incelendiğinde, değerlerin 0,92 ve 3,79 arasında değiştiği belirlendi. Otoklav grubuna ait ortalama $\Delta \mathrm{E} 00$ değerleri $(3,79)$; diğer gruplardan istatistik olarak anlamlı derecede daha yüksek bulunurken diğer gruplar arasında istatistik olarak anlamlı fark bulunmadı $(0,92-1,37)$ ( $P>0,05)$. Deney gruplarına ait ortalama Ra değerleri ve standart sapmaları Tablo 3'te gösterildi. Dezenfeksiyon işlemi öncesi ve sonrasında yüzey 
pürüzlülüğü değerlendirildiğinde dezenfeksiyon sonrası kontrol, efervesan tablet, nötral sabun ve dermal dezenfektan gruplarında $\mathrm{Ra}$ değerleri istatistik olarak anlamlı derecede daha yüksek bulundu $(P<0,05)$ (Şekil 2). Dezenfeksiyon öncesi nötral sabun ve otoklav grubunun Ra değeri arasında istatistik olarak anlamlı derecede farklılık bulundu $(P<0,05)$. Nötral sabun grubunun dezenfeksiyon sonrası Ra değeri klorheksidin glukonat ve otoklav gruplarından anlamlı derecede daha yüksek bulundu $(P<0,05)$.

Tablo 2. Deney gruplarına ait ortalama $\Delta E 00$ değerleri

\begin{tabular}{|llll|}
\hline Dezenfeksiyon Yöntemi & $\mathrm{n}$ & Ortalama & $\begin{array}{l}\text { Standart } \\
\text { Sapma }\end{array}$ \\
\hline Kontrol & 10 & $0,996 \mathrm{~B}$ & 0,356 \\
\hline Efervesan tablet & 10 & $0,926 \mathrm{~B}$ & 0,274 \\
\hline Nötral sabun & 10 & $1,373 \mathrm{~B}$ & 0,516 \\
\hline Dermal dezenfektan & 10 & $1,335 \mathrm{~B}$ & 0,283 \\
\hline Klorheksidin glukonat & 10 & $1,205 \mathrm{~B}$ & 0,381 \\
\hline Otoklav & 10 & $3,787 \mathrm{~A}$ & 0,465 \\
\hline Toplam & 60 & 1,604 & 1,065 \\
\hline
\end{tabular}

Ortak büyük harfe sahip gruplar arasındaki fark istatistiksel olarak anlam/ı değildir $(P>0,05)$

Tablo 3. Deney gruplarına ait ortalama yüzey pürüzlülüğü değerleri

\begin{tabular}{|c|c|c|}
\hline $\begin{array}{l}\text { Dezenfeksiyon } \\
\text { yöntemi } \\
(n=10)\end{array}$ & $\begin{array}{l}\text { Dezenfeksiyon öncesi } \\
\text { yüzey pürüzlülüğü } \\
\text { Ort }( \pm S S)\end{array}$ & $\begin{array}{l}\text { Dezenfeksiyon sonrası } \\
\text { yüzey pürüzlülüğü } \\
\text { Ort }( \pm S S)\end{array}$ \\
\hline Kontrol & $1,47( \pm 0,22) \quad b \quad A B$ & $1,76( \pm 0,29)$ a $A C$ \\
\hline Efervesan tablet & $1,47( \pm 0,25)$ b $A B$ & $1,72( \pm 0,26)$ a $A B$ \\
\hline Nötral sabun & $1,40( \pm 0,20) \quad$ b $B$ & $1,91( \pm 0,12)$ a $A$ \\
\hline Dermal dezenfektan & $1,59( \pm 0,17) \quad$ b $A B$ & $1,84( \pm 0,23)$ a $A D$ \\
\hline Klorheksidin glukonat & $1,58( \pm 0,21) \quad$ a $A B$ & $1,53( \pm 0,33)$ a $B$ \\
\hline Otoklav & $1,62( \pm 0,21)$ a $A$ & $1,65( \pm 0,26)$ a $B C D$ \\
\hline
\end{tabular}

Yatay olarak ortak küçük harfe sahip gruplar arasındaki fark anlamlı değildir $(P>0,05)$.

Dikey olarak ortak büyük harfe sahip gruplar arasındaki fark anlam/ı değildir $(P>0,05)$.

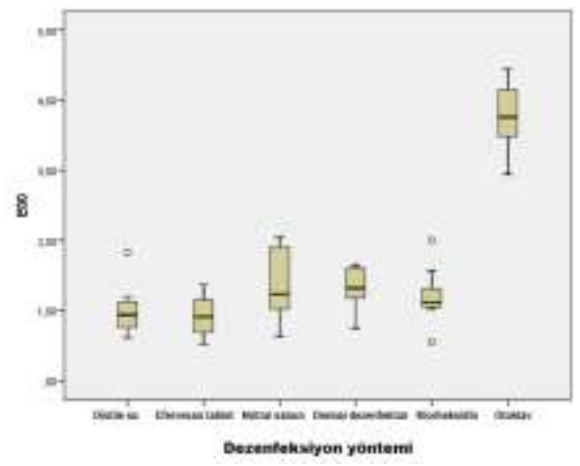

Şekil 1. Grupların ortalama $\Delta \mathrm{E} 00$ değerleri

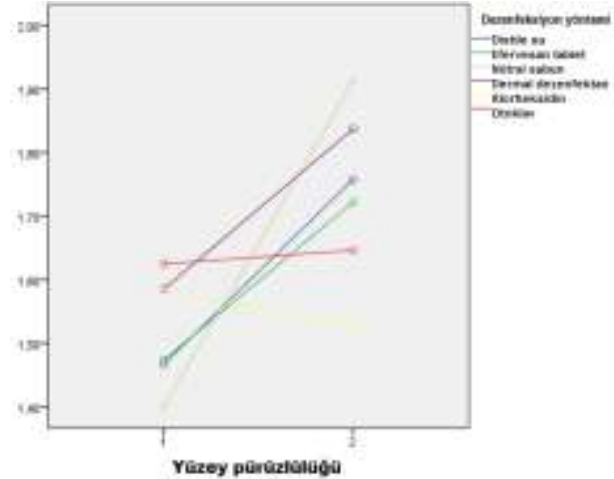

Şekil 2. Grupların ortalama yüzey pürüzlülüğü değerlerinin dezenfeksiyon işlemleri sonrası değişimi

\section{TARTIŞMA}

Çalışmada, maksillofasiyal silikonların dezenfeksiyon sonrası yüzey pürüzlülüğü ve renk değişimi değerleri incelendiğinde, otoklav uygulamasının anlamlı renk değişimine sebep olduğu ve distile su, efervesan tablet, nötral sabun ve dermal dezenfaktan uygulamalarının ise yüzey pürüzlülüğünü arttırdığı belirlendi. Bu nedenle çalışmanın hipotezi kısmen reddedildi.

İnsan derisi, deri yüzeyinde doğal olarak bulunan ve yaşayan bakteri ve mantar gibi mikroorganizmalardan zengindir. Aşırı ISı ve nem varlığında, kontrol edilemeyen diyabet vakalarında ve uzun dönemli antibiyotik kullanımı sonrasında, bu mikroorganizmalar biyofilm formasyonuna ve enfeksiyonlara neden olabilmektedir. ${ }^{29} \mathrm{Bu}$ nedenle defekt bölgesi ve çevre dokularla temasta olan yüz protezlerinin temizliği ve dezenfeksiyonu oldukça önemlidir.

Silikon yüz protezleri, materyalin yapısında meydana gelen bozulmalar nedeniyle genellikle 3 ay ile 2 yıl arasında değişen kullanım ömrüne sahiptirler. ${ }^{30-32}$ Protezlerde meydana gelen bozulmaların sebepleri arasında UV ışınlarına maruz kalma, hava kirliliği, nem ve ISı değişiklikleri, ${ }^{10,33}$ kozmetik ürünler ve hasta tarafından uygulanan temizleme ajanları (benzen ve ksilen içeren güçlü çözücüler gibi) başta gelmektedir. ${ }^{10,14,34}$ Lemon ve ark. $^{9}$ ve Ishigami ve ark. ${ }^{14}$ yüz protezlerinin yeniden yapım nedenlerini, UV ışınları nedeniyle protezlerde oluşan renk değişikliği ve protez dezenfeksiyon ajanlarının kullanımına bağlı olarak materyal yüzeyindeki porözitelerde mikroorganizma birikimi olarak bildirmişlerdir. Diğer yandan bu dış etkilerin hiç birine maruz kalmayan karanlık ortamda, ısı ve nem koşullarının optimal olduğu koşullarda bekletilen silikon elastomerlerin de polimer yapısında devam eden çapraz bağlantı reaksiyonları ve pigmentlerin etkileşimleri sebebiyle bir miktar renk 
değişimi gösterdiği bildirilmiştir. ${ }^{35}$ Güneşten gelen UV ışınları ve materyalin yapısal reaksiyonları sebebiyle bozulma hasta ve hekim tarafından kontrol edilmesi mümkün olmayan sebepler iken protez dezenfeksiyonunda kullanılan yöntemler arasında materyali en az etkileyeni seçmek, yapımı zahmetli ve maliyetli olan bu protezlerin ömrünü uzatmak için önemli bir konudur. Bu sebeple çalışmada bu protezlerin dezenfeksiyonu için sıklıkla kullanılan yöntemlerin renk değişimi ve yüzey pürüzlülüğü üzerindeki etkisi incelendi.

Yüz protezlerinin yapımında sıklıkla kullanılan silikonların temizliğinde kullanılan dezenfeksiyon yöntemleri; biyofilm tabakasının mekanik yöntemlerle uzaklaştırılması (diş fırçası ile fırçalama veya su/nötral sabunla el ile yıkama), temizleme tabletleri (efervesan tabletler), \%2-4'lük konsantrasyondaki klorheksidin, $\% 0,5-1$ 'lik konsantrasyondaki klorheksidin ve fitoterapi uygulamalarıdır. ${ }^{29}$ Guiotti ve ark. ${ }^{29}$ maksillofasiyal silikonların dezenfeksiyonunda kullanılan su ve nötral sabun ile yıkama yönteminin $S$ aureus ve $C$ albicans tipindeki mikroorganizmalara karşı etkili bir yol olduğunu bildirmişlerdir. Dezenfeksiyon yöntemlerinin biyofilm formasyonunu azalttığı bilinmektedir, ancak uygulanan yöntemin silikonlarda bozulmaya neden olmaması gerekmektedir. Maksillofasiyal silikonların dezenfeksiyonu için önerilen ideal bir dezenfeksiyon yöntemi bulunmamaktadır. Ancak biyofilm tabakasının kaldırılmasında mekanik temizliğin etkili olduğu bildirilmiştir. Yüz protezlerinin dezenfeksiyonunda antibakteriyel sabunlar ve klorheksidin ucuz ve hastalar tarafından kolay ulaşılabilir dezenfektanlar olmaları sebebiyle sık kullanılmaktadır. Ancak bu temizleme ajanlarının maksillofasiyal protezlerde renk değişimine etkisini karşılaştıran çalışmalar sınırlıdır. ${ }^{4,10,12,36}$ Bu nedenle bu çalışmada, maksillofasiyal protezlerin dezenfeksiyonu için kullanılabilecek yöntemlerin, renk değişimi ve yüzey pürüzlülüğüne etkisi ve yöntemlerin birbiri ile karşılaştırıması amaçlanmıştır.

Maksillofasiyal protezler defekt bölgesindeki ve çevresindeki dokularla renk uyumu gösterdiği sürece kullanılabilir, renk değişimi gözle görülebilir ve dikkat çekici düzeye ulaştığında protezlerin değiştirilmesini gerektirir. ${ }^{12}$ Protezlerin klinik kullanımında göz ile yapılan bu değerlendirme protezin kullanım ömrünü belirler. Ancak bilimsel çalışmalarda maksillofasiyal silikonların renk değişiminin belirlenmesinde renk ölçüm cihazlarından spektrofotometre sıklıkla kullanımaktadır.,10,12,36 Spektrofotometre ile yapılan renk değişimi ölçümü, güvenilir, hassas ve tekrarlanabilen bir ölçüm yöntemidir ve göz ile fark edilemeyen renk değişimlerinin belirlenmesini sağlamaktadır. Rengi ölçülecek yüzeylerden cihaz ile yapılan ölçümler sonucu renk koordinatları elde edilir ve bu koordinatlar kullanılarak farklı ölçümler arasındaki renk farkı belirlenir. CIE (Comission Internationale de l'Eclairage), dental materyaller için renk değişimi formüllerini belirlemiştir ve son yıllara kadar bu formüllerden CIELAB formulü yaygın olarak kullanılmıştır. Buna göre renk değişimini sayısal olarak ifade eden CIELAB $\triangle \mathrm{E}$ değeri; 1,1 'den büyük ise değişim insan gözü tarafından ayırt edilebilmektedir ancak $\Delta \mathrm{E}$ değeri 3 ve üzerine çıktığında, renk değişimi klinik olarak kabul edilemez boyuta ulaşmaktadır. ${ }^{1,36}$ Ancak, son yıllarda, ölçülen ve insan gözü tarafından algılanan renk değişimi arasındaki farkı azalmak için CIEDE2000 formulünün kullanımı önerilmektedir. ${ }^{27,28} \mathrm{Bu}$ sebeple çalışmamızda renk değişiminin tespitinde CIEDE2000 formülü kullanılmıştır. Bir materyalin renk değişminin hesaplanması CIEDE2000 formülüne göre yapıldığında CIELAB değerlerinden farklıık göstermektedir. Buna göre renk farklılı̆ı sonuçlarının yorumlanmasında kullanılan eşik değerlerin de aynı formül kullanılarak belirlenmiş olması gerekir. Maksillofasiyal silikonların renk değişimi nitelendirmek için yapılmış sınırlı sayıdaki eşik değer çalışmaları incelendiğinde; Paravina ve $\operatorname{ark}^{1}$. açık ve koyu tonlar için algılanabilir renk farkı (CIELAB/ CIEDE2000) değerini sırasıyla $1,1 / 0,7$ ve $1,6 / 1,2$ olarak, kabul edilebilir renk farkı değerini ise sırasıyla 3.0/2.1 ve 4.4/3.1 olarak belirlemişlerdir. Leow ${ }^{37}$ ise, maksillofasiyal silikonların renk değişiminde eşik değer (CIELAB) olarak, açık tonlar için algılanabilir 0,8 ve kabul edilebilir 1,8 olarak, koyu tonlar için ise algılanabilir 1,3 ve kabul edilebilir 2,6 olarak belirlemişlerdir. Bu çalışmada kullanılan maksillofasiyal silikon açık pembe renkte pigment kullanılarak renklendirilmiştir. Uygulanan dezenfeksiyon yöntemlerinin meydana getirdiği renk değişimleri yani $\Delta \mathrm{E} 00$ değerleri eşik değerlere göre değerlendirildiğinde otoklav grubu dışındaki tüm gruplarda kabul edilebilir düzeyde renk değişimi gözlenmiştir.

Kimyasal protez temizleme ajanları etki mekanizmalarına göre, hipokloritler, peroksitler, enzim ilaveli nötral peroksitler, enzimleri asitler ve dezenfektanlar olarak sınıflandırılabilmektedir. Fakat kompozisyonlarına bağlı olarak kimyasal temizleme ajanlarının, yumuşak astar materyallerinin su emilimini ve çözünülebilirliğini arttırarak bu materyallerin fiziksel özelliklerinde bozulmaya neden olduğu bildirilmektedir. ${ }^{10,38,39}$ $\mathrm{Bu}$ nedenle protez temizliğinde kullanılacak kimyasal temizleyici ajanın seçiminde antimikrobiyal özelliğinin yanı sıra, materyalin fiziksel özelliklerini koruması da göz önünde bulundurulmalıdır. ${ }^{10,40}$ Mevcut literatür in- 
celendiğinde maksillofasiyal silikonların çeşitli dezenfeksiyon işlemlerinin renk değişimi ve çeşitli fiziksel özellikleri üzerine etkisini inceleyen çeşitli çalışmalar yapılmışır. Ancak bu çalışmalarda renk değişimi CIELAB $\Delta \mathrm{E}$ formülü kullanılarak hesaplandığı için $\Delta \mathrm{E}$ değerlerinin bizim çalışmamızda bulunanlar ile direk olarak karşılaşıırmak mümkün değildir. Yapılan çalışmalarda, çalışmamı bulgularına benzer şekilde efervesan tabletlerin nötral sabun ve klorheksidin ile kıyaslandığında en az renk değişimine sebep olduğu tespit edilmiştir. ${ }^{10,12,36}$ Ancak efervesan tablet kullanımında ortaya çıkan problem alkalin peroksit içeren tabletlerin oksijen salınımı mekanizmasıyla materyalin yüzeyindeki pigmentleri uzaklaştırabilmesidir. Bu sebeple alkalin peroksit içeren efervesan tabletlerin maksillofasiyal protezlerin dezenfeksiyonunda kullanımasından kaçınıımalıdır. ${ }^{10,11}$ Goiato ve ark. ${ }^{36}$ maksillofasiyal protezlerin temizliğinde pratikte sıkça kullanılan dezenfeksiyon yöntemleri olan klorheksidin ve nötral sabunu karşılaştırdıklarında klorheksidinin daha fazla renk değişimine yol açtığını bildirmişlerdir. Bu çalışmada ise klorheksidin, nötral sabuna göre istatistiksel olarak anlamlı olamamakla birlikte daha az renk değişimine sebep olmuştur. Çalışmaların sonuçları arasındaki farklılıkların dezenfektanların uygulama tekniklerinde, uygulama sürelerinde ve renk farkı hesaplanmasındaki farklardan kaynaklanabileceği düşünülmektedir. Parmakla ovarak veya firçalama ile uygulanması sonucu nötral sabunun, maksillofasiyal silikonun üst yüzeyinden renk pigmentlerini kaldırabileceği belirtilmektedir. ${ }^{10,41}$ Diğer yandan Chamaria ve ark. ${ }^{42}$ distile su (kontrol grubu), antibakteriyel sabun ( $5 \mathrm{dk}$ ) ve $\% 2^{\prime}$ lik klorheksidin glukonat kullanarak dezenfekte ettikleri ve maksillofasiyal silikonların renk stabilitesini değerlendirmişlerdir. En yüksek renk değişimi pigment içeren silikonlarda antibakteriyel sabunla dezenfeksiyon sonucu oluşmuş, \%2'lik klorheksidin glukonat kullanımında klinik olarak kabul edilebilir renk değişikliği meydana gelmiştir. Bu çalışmada ise; kontrol ve efervesan tablet grubunda $1,1^{\prime}$ 'den küçük, nötral sabun ve dermal dezenfektan grubunda insan gözü tarafindan seçilebilir $(>1,1)$ ve otoklav grubunda ise klinik olarak kabul edilemez $(\geq 3)$ bulunmuştur.

Yüzey pürüzlülüğü materyallerin mekanik özelliklerinin tespitinde önemli bir belirteçtir. Çünkü materyal yüzeyinde bulunan düzensiz alanlar, çatlak ve korozyon için çekirdekleşme alanları oluşturabilir. ${ }^{25,26}$ Dezenfeksiyon işlemleri, maksillofasiyal silikonların iç yapısından bir takım maddelerin uzaklaşarak dezenfeksiyon solüsyonuna veya suya geçmesi nedeniyle materyalin yüzey karakteristiğini etkilemektedir. ${ }^{10,12} \mathrm{Bu}$ çalışmada, çeşitli dezenfeksiyon işlemlerinin yüzey pürüzlülüğüne etkisi incelendiğinde, yüzey pürüzlülüğünün kontrol, efervesan tablet, nötral sabun ve efervesan tablet gruplarında anlamlı olarak artış gösterdiği görülmüştür. Bu durum dezefenfeksiyon işlemlerinin, maksillofasiyal silikonların yüzey özelliklerini değiştirdiğini göstermektedir. En yüksek yüzey pürüzlülüğü değeri nötral sabun grubunda 1,91 olarak bulunmuştur. Nötral sabunun parmakla ovularak uygulanması nedeniyle materyalin yüzeyinden daha fazla madde uzaklaştırarak pürüzlülüğü arttırdığı düşünülmektedir. Babu ve ark. ${ }^{25}$ sodyum perborat monohidrat, \%4'lük klorheksidin glukonat ve nötral sabun kullandıkları çalışmalarında maksillofasiyal silikonların yüzey pürüzlülüğünün dezenfeksiyon işlemleri nedeniyle değişmediğini belirtmektedirler.

Eleni ve ark. ${ }^{19}$ farklı dezenfeksiyon yönteminin (mikrodalga, hipoklorit solüsyonu, nötral sabun ve antimikrobiyal ajan) maksillofasiyal protezlerin mekanik özelliklerine etkisini inceledikleri çalışmalarında mikrodalga ve hipoklorit yöntemlerinin mekanik özelliklerde daha fazla etkiye yol açtığını ve maksillofasiyal silikonların dezenfeksiyonunda antimikrobiyal ajanların ve nötral sabun kullanımının daha uygun olabileceğini belirtmişlerdir. Goiato ve ark. ${ }^{34}$ nötral sabun ve efervesan tablet uygulamalarının maksillofasiyal silikonların sertliğine ve yüzey pürüzlülüğüne etkisini inceledikleri çalışmalarında, sertlik ve pürüzlülük değerlerinin dezenfeksiyon yöntemlerinden anlamlı olarak etkilenmediklerini belirlemişlerdir.

Maksillofasiyal protezlerin dezenfeksiyonu için günlük 3-5 dakika önerilmektedir. Bu da yıllık olarak yaklaşık 1800 dk'ya karşılık gelmektedir. ${ }^{20,42}$ Çalışmada kullanılan dezenfeksiyon yöntemleri (otoklav hariç) 15 gün boyunca günde 2 defa uygulanmıştır. Efervesan tablet ve klorheksidin grubunda, dezenfeksiyon süreleri sırasıyla $150 \mathrm{dk}$ ve $300 \mathrm{dk}$ 'dır. Bu sürelerde yaklaşık olarak 1 ve 2 aylık dezenfeksiyon işlemlerini kapsamaktadır. Bu nedenle dezenfeksiyon işlemlerinin maksillofasiyal silikonların renk değişimini değerlendirebilmek için daha uzun kullanımları içeren çalışmalara intiyaç vardır. Bu çalışmada kullanılan dezenfeksiyon yöntemleri değerlendiğinde klorheksidin glukonat kullanımının maksillofasiyal silikonların dezenfeksiyonunda uygun bir yöntem olabileceği düşünülmektedir. Ayrıca maksillofasiyal silikonlardaki renk stabilitesini, silikon içerisine katılan pigmentler, opaklaştırıclar, UV koruyucular ve polimerizasyon yöntemi etkileyebilmektedir. Çalışmada tek renk ve tek tip maksillofasiyal silikonun kullanılması çalışmanın sınılamaları arasında yer almaktadır. 


\section{SONUÇ}

Otoklavda yapılan dezenfeksiyonun maksillofasiyal silikonların renk değişimi üzerinde önemli etkisi bulunmaktadır. Dezenfeksiyon işlemleri genellikle maksillofasiyal silikonların yüzey pürüzlülüğünü arttırmaktadır. Çalışmanın sonuçları değerlendirildiğinde klorheksidin glukonat, maksillofasiyal silikonlarda klinik olarak kabul edilebilir renk değişimine neden olmuştur ve ayrıca materyalin yüzey pürüzlülüğünde artışa neden olmamıştır.

NOT: Calışmada herhangi bir yazar, kurum ya da kurulus ile çıkar çatışması içerisinde bulunmamaktadır. Makale daha önce hiçbir yerde yayınlanmamış ve yayınlanmak üzere işlem görmemektedir

\section{KAYNAKLAR}

1. Paravina RD, Majkic G, Del Mar Perez M, KiatAmnuay S. Color difference thresholds of maxillofacial skin replications. J Prosthodont 2009; 18:618-25.

2. Parkin DM, Pisani $P$, Ferlay J. Estimates of the worldwide incidence of eighteen major cancers in 1985. Int J Cancer 1993; 54:594-606.

3. Karayazgan B, Gunay Y, Evlioǧlu G. Improved edge strength in a facial prosthesis by incorporation of tulle: A clinical report. J Prosthet Dent 2003; 90:526-9.

4. Guiotti $A M$, Goiato MC, Dos Santos DM, VechiatoFilho AJ, Cunha BG, Paulini MB, Moreno A, De Almeida MTG. Comparison of conventional and plant-extract disinfectant solutions on the hardness and color stability of a maxillofacial elastomer after artificial aging. J Prosthet Dent 2016; 115:501-8.

5. Andres CJ, Haug SP, Brown DT, Bernal G. Effects of environmental factors on maxillofacial elastomers: Part II:Report of survey. J Prosthet Dent 1992; 68:519-22.

6. Kiat-Amnuay S, Johnston DA, Powers JM, Jacob RF. Color stability of dry earth pigmented maxillofacial silicone A-2186 subjected to microwave energy exposure. J Prosthodont 2005; 14:91-6.

7. Waters MGJ, Jagger RG, Polyzois GL. Wettability of silicone rubber maxillofacial prosthetic materials. J Prosthet Dent 1999; 81:439-43.

8. Khalaf S, Ariffin Z, Husein A, Reza F. Surface coating of gypsum-based molds for maxillofacial prosthetic silicone elastomeric material: evaluating different microbial adhesion. J Prosthodont 2017; 26:664-9.
9. Lemon JC, Chambers MS, Jacobsen ML, Powers JM. Color stability of facial prostheses. J Prosthet Dent 1995; 74:613-8.

10. Goiato MC, Pesqueira AA, Santos DM Dos, Zavanelli AC, Ribeiro PDP. Color stability comparison of silicone facial prostheses following disinfection. J Prosthodont 2009; 18:242-4.

11. Gary JJ, Smith CT. Pigments and their application in maxillofacial elastomers: A literature review. J Prosthet Dent 1998; 80:204-8.

12. Pesqueira AA, Goiato MC, dos Santos DM, Haddad MF, Ribeiro PP, Coelho Sinhoreti MA, Sundefeld MLMM. Effect of disinfection and accelerated aging on color stability of colorless and pigmented facial silicone. J Prosthodont 2011; 20:305-9.

13. Pesqueira AA, Goiato MC, Dos Santos DM, Haddad MF, Moreno A. Effect of disinfection and accelerated ageing on dimensional stability and detail reproduction of a facial silicone with nanoparticles. J Med Eng Technol 2012; 36:21721.

14. Ishigami T, Tanaka $Y$, Kishimoto $Y$, Okada M. A facial prosthesis made of porcelain fused to metal: A clinical report. J Prosthet Dent 1997; 77:564-7.

15. Micheline Dos Santos D, Goiato MC, Moreno A, Pesqueira AA, Dekon SFDC, Guiotti AM. Effect of addition of pigments and opacifier on the hardness, absorption, solubility and surface degradation of facial silicone after artificial ageing. Polym Degrad Stab 2012; 97:1249-53.

16. Haug SP, Moore BK, Andres CJ. Color stability and colorant effect on maxillofacial elastomers. Part II: Weathering effect on physical properties. J Prosthet Dent 1999; 81:423-30.

17. Atay A, Günay Y. Çene Yüz Protezlerinde Bakım. Atatürk Üniv Diş Hek Fak Derg 2007; s2:22-5.

18. Anusavice K, Shen C, Rawls HR. Phillips' Science of Dental Materials. 12th ed. St. Louis: Elsevier, Saunders; 2013. p. 3-537.

19. Eleni PN, Perivoliotis D, Dragatogiannis DA, Krokida MK, Polyzois GL, Charitidis CA, Ziomas I, Gettleman L. Tensile and microindentation properties of maxillofacial elastomers after different disinfecting procedures. J Mech Behav Biomed Mater 2013; 28:147-55.

20. Eleni PN, Krokida MK, Polyzois GL, Gettleman L. Effect of different disinfecting procedures on the hardness and color stability of two maxillofacial elastomers over time. J Appl Oral Sci 2013; 21:278-83.

21. Kamble SS, Khandeparker RV, Somasundaram P, 
Raghav S, Babaji RP, Varghese TJ. Comparative evaluation of dimensional accuracy of elastomeric impression materials when treated with autoclave, microwave, and chemical disinfection. J Int Oral Health 2015; 7:22-4.

22. Nikawa H, Hayashi S, Nikawa $\mathrm{Y}$, Hamada T, Samaranayake LP. Interactions between denture lining material, protein pellicles and Candida albicans. Arch Oral Biol 1993; 38:631-4.

23. Radford DR, Sweet SP, Challacombe SJ, Walter JD. Adherence of Candida albicans to denture-base materials with different surface finishes. J Dent 1998; 26:577-83.

24. Gedik H, Özkan YK. The effect of surface roughness of resilient liner materials on the silicone-based. Oral Health Prev Dent 2009; 7:347-53.

25. Babu AS, Manju V, Gopal VK. Effect of chemical disinfectants and accelerated aging on maxillofacial silicone elastomers: An in vitro study. Indian J Dent Res 2018; 29:67-73.

26. Al-Dharrab AA, Tayel SB, Abodaya MH. The effect of different storage conditions on the physical properties of pigmented medical grade I silicone maxillofacial material. ISRN Dent 2013; 2013:582051.

27. Pecho OE, Ghinea $R$, Alessandretti $R$, Pérez MM, Della Bona $A$. Visual and instrumental shade matching using CIELAB and CIEDE2000 color difference formulas. Dent Mater 2016; 32:82-92.

28. Commission Internationale de I'Eclairage. CIE technical report: improvement to industrial colourdifference evaluation. CIE Pub No. 142-2001. Vienna, Austria: CIE Central Bureau; 2001.

29. Guiotti AM, Cunha BG, Paulini MB, Goiato MC, dos Santos DM, Duque C, Caiaffa KS, Brandini DA, Narciso de Oliveira DT, Brizzotti NS, Almeida MT. Antimicrobial activity of conventional and plantextract disinfectant solutions on microbial biofilms on a maxillofacial polymer surface. J Prosthet Dent 2016; 116:136-43.

30. Karakoca S, Aydin C, Yilmaz H, Bal BT. Retrospective study of treatment outcomes with implant-retained extraoral prostheses: Survival rates and prosthetic complications. J Prosthet Dent 2010; 103:118-26.

31. Visser A, Raghoebar GM, van Oort RP, Vissink A. Fate of implant-retained craniofacial prostheses: life span and aftercare. Int J Oral Maxillofac Implants 2008; 23:89-98.

32. Hooper SM, Westcott T, Evans PLL, Bocca AP,
Jagger DC. Implant-supported facial prostheses provided by a maxillofacial unit in a U.K. Regional Hospital: Longevity and patient opinions. J Prosthodont 2015; 14:183-91.

33. Chen MS, Udagama A, Drane JB. Evaluation of facial prostheses for head and neck cancer patients. J Prosthet Dent 1981; 46:538-44.

34. Goiato MC, Pesqueira AA, dos Santos DM, Dekon SFDC. Evaluation of hardness and surface roughness of two maxillofacial silicones following disinfection. Braz Oral Res 2009; 23:49-53.

35. Bankoğlu M, Oral I, Gül EB, Yilmaz H. Influence of pigments and pigmenting methods on color stability of different silicone maxillofacial elastomers after 1-year dark storage. J Craniofac Surg 2013; 24:720-4.

36. Goiato MC, Haddad MF, Pesqueira AA, Moreno A, dos Santos DM, Bannwart LC. Effect of chemical disinfection and accelerated aging on color stability of maxillofacial silicone with opacifiers. J Prosthodont 2011; 20:566-9.

37. Leow MEL, Ow RKK, Lee MH, Huak CY, Pho RWH. Assessment of colour differences in silicone hand and digit prostheses: Perceptible and acceptable thresholds for fair and dark skin shades. Prosthet Orthot Int 2006; 30:5-16.

38. Budtz-Jörgensen E. A 3-months ' study of enzymes as denture cleansers. J Oral Rehabil 1978; 5:35-9.

39. Goll G, Smith DE, Plein JB. The effect of denture cleansers on temporary soft liners. J Prosthet Dent 1983; 50:466-72.

40. Nikawa $H$, Iwanaga $H$, Hamada $T$, Yuhta S. Effects of denture cleansers on direct soft denture lining materials. J Prosthet Dent 1994; 72:657-62.

41. Gasparro FP, Mitchnick M, Nash JF. A Review of sunscreen safety and efficacy. Photochem Photobiol 1998; 68:243-56.

42. Chamaria A, Aras MA, Chitre V, Rajagopal P. Effect of chemical disinfectants on the color stability of maxillofacial silicones: An in vitro study. J Prosthodont 2019; 28:e869-72.

\section{Yazışma Adresi}

Dr. Meral KURT

Gazi Üniversitesi Diş Hekimliği Fakültesi, Protetik Diş Tedavisi Anabilim Dalı, Bişkek Cd.(8.Cd.) 82.Sk. No:4 06510 Emek, Ankara, Türkiye

Tel: +90-312-2034193 Fax: +90-312-2239226

e-posta:dt.meral@gmail.com 